Mark A. Cohen

\title{
The Social Cost of a Racially Targeted Police Encounter $^{1}$
}

\begin{abstract}
This paper identifies the individual components of social harm associated with a hypothetical racially targeted police encounter. Individuals who believe they are being targeted by police because they are members of a racial minority may suffer from fear of physical harm and humiliation by the encounter itself. However, the very fact that individuals will be racially targeted for a police encounter also causes harm to other members of the minority group even if they are not directly subject to an unwarranted encounter. In addition to fear and anxiety over the risk of such an encounter, they will often undertake costly avoidance behaviors to reduce their risk, or to mitigate the risk of any harm if such an encounter occurs. In addition, other members of society who value a nondiscriminatory policing policy might be willing to pay to reduce such unwarranted police encounters, and hence suffer a loss from this policing policy. In addition to discussing possible methodologies for estimating these cost components, this paper raises several issues that must be resolved - such as how to deal with the difference between perceived and actual racially targeted police encounters.
\end{abstract}

Keywords: police practices; racial targeting; social cost of discrimination.

JEL classifications: K14; J15.

\section{Introduction}

Suppose a police officer stops a vehicle or approaches an individual and requests an ID and the individual believes the likelihood that this police encounter occurred was increased by the individual's race. In other words, the individual believes that

1 This paper was first prepared for the NYU Law Cost-Benefit Analysis Conference, sponsored by the Policing Project at NYU School of Law, February 9-10, 2017. Thanks but no blame for helpful comments from participants in the conference, the Journal editors, and two anonymous referees.

Mark A. Cohen: Justin Potter Professor of American Competitive Enterprise and Professor of Law, Owen Graduate School of Management, Vanderbilt University, 401 21st Avenue South, Nashville TN 37205, USA, e-mail: mark.cohen@ owen.vanderbilt.edu and Resources for the Future, 1616 P Street, NW, Washington, DC 20036, USA 
the decision to stop was not racially neutral. What is the social harm from this encounter? ${ }^{2}$

The answer to this question is complex and depends heavily upon society's values as well as the values and perceptions of the individual who encounters the police. In Section 4, I address some of the complexities of determining how society defines a racially targeted encounter. First, however, Section 2 focuses on what these harms are from the perspective of victims and the public at large, while Section 3 discusses how to monetize these harms.

As a starting point, the analysis is not concerned with whether or not the police encounter is actually racially motivated. As will become clear later in the paper, there will be costs associated with such a police encounter regardless of whether it is actually racially motivated. In other words, perceived racial targeting may be harmful regardless of whether or not it actually occurs. Thus, we start from the point of the view of individuals who believe they are being targeted. Then, we expand the analysis to consider alternative motivations for the police encounter and how that affects the estimated social costs.

Although the paper focuses on the costs of racially targeted policing, in theory there might be social benefits of racial targeting to the extent they involve more efficient policing (i.e., reduce crime at a lower overall cost to society). Of course, even if racial targeting improves police effectiveness, it comes at a cost to the racially targeted group. ${ }^{3}$

Note that this paper focuses on identifying and estimating harm and does not discuss how this estimate might be used. In particular, while social harm due to racially targeted policing would certainly belong in a benefit-cost analysis of a program designed to reduce targeted policing, whether or not it is appropriate for use in a civil compensation scheme is outside the scope of this paper. ${ }^{4}$

2 Throughout this paper, I use the terms "social harm," "harm," and "cost" interchangeably. In the context of racially motivated police encounters, I assume that harms suffered by individuals who are racially targeted are indeed social harms. In some instances, such as theft of money, individual harms might be considered external costs that are private but not social harms because it is a transfer of wealth from one party to another - although this itself is a controversial issue. See Cohen (2005) for a discussion of this issue in the context of crime.

3 The trade-off between more efficient policing and any reduction in civil liberties to affected minorities and the public at large was previously studied in the context of airport security screening by Viscusi and Zeckhauser (2003). See also the discussion in Section 4.1 below.

4 For the difference between valuing nonpecuniary losses for purposes of social benefit-cost analysis versus victim compensation in tort cases, see Havrilesky (1993) and Viscusi (2000). 


\section{Defining harm from a racially targeted police encounter}

This section focuses on the fundamental issue of what harm is perceived to be by victims, potential victims, and the public at large. In general, there are four sets of harm from a police encounter that is perceived to be racially motivated: (1) harm endured by the individual who perceives they are being targeted, (2) harm to other racial minorities who have increased fear that they will be targeted in the future, (3) harm to others in society who value a nondiscriminatory police force, and (4) police and criminal justice system costs associated with the targeted encounter and any subsequent ramifications. Each of these four harms will be considered in turn.

\subsection{Harm to targeted individual}

While most traffic stops or police encounters are likely to end without incident, some circumstances end up with police using force. While likely to be infrequent, excessive police use of force is a real concern and may result in physical injury to a citizen. ${ }^{5}$ In addition to the physical injury and resulting pain and suffering endured by such a targeted individual, members of the racial or ethnic group being targeted who are not physically harmed but believe they are being racially targeted during a police encounter might endure psychological distress due to the fear and uncertainty associated with the encounter. In particular, the individual might perceive a risk of physical harm - and even if not, will no doubt suffer some harm due to the opportunity cost of the time spent on the police encounter. The opportunity cost would include the time spent with the direct police interaction as well as any collateral consequences such as an arrest or other involvement with the criminal justice system.

In addition, however, an individual who believes they have been racially targeted for a police encounter might suffer from indignation or humiliation from the belief that they are members of a group that is being treated unfairly by police. The harm associated with humiliation is independent of any risk or fear of injury or time losses due to an actual unwarranted police encounter. Humiliation might result in psychological harm including anxiety, depression, and even post-traumatic stress

5 While data are scarce, and the FBI is currently conducting a national study of the incidence of police use of excessive force. A study of large police agencies representing about $60 \%$ of all sworn officers nationwide in 2002, found over 2,000 incidents where an officer was disciplined for a citizen complaint of excessive force (Hickman, 2006). 
disorder. $^{6}$ In fact, it is possible that over time, humiliation due to perceived unequal treatment might lead to physical health impacts. ${ }^{7}$

\subsection{Harm to other minorities who did not encounter the police}

There are three identifiable harms to members of the racial minority that is being targeted but who do not actually encounter police during this incident. First, individuals going about their daily lives might fear that they will become victims of a targeted police encounter. This harm is similar to the harm to those who are actually targeted. In this instance, however, one might discount this harm to account for the perceived probability that the individual will have such an encounter. This calculation is not straightforward, however, as one cannot simply multiply the perceived probability of being targeted by the disutility of being targeted. Instead, one would need to account for the disutility that individuals place on risk, i.e., include a risk premium in the calculation.

Second, members of the racial minority might suffer from indignation or humiliation from the knowledge that they are members of a group that is being treated unfairly by police. Again, this is similar to the humiliation of those who are actually racially targeted - although presumably to a lesser extent.

Third, members of the racial minority who believe they are potentially subject to racial targeting might engage in "avoidance" behaviors to reduce the likelihood that they will be directly harmed by a targeted police encounter. Real life examples of avoidance behaviors in this context include staying away from certain neighborhoods, driving slower or not driving a car at certain times or areas or perhaps taking an Uber instead of driving. Other avoidance behaviors are more subtle, such as storing automobile registration and insurance information in an accessible location such as a sun visor instead of a glove compartment. ${ }^{8}$ All of these efforts involve real or opportunity costs - whether it is actual dollars, the value of time, and/or other psychic costs that are incurred to reduce the risk of a targeted encounter or reduce the risk of collateral consequences if an unwarranted targeted encounter should occur.

6 See for example, Torres and Bergner (2010), for a discussion of the psychological consequences of humiliation.

7 See for example, Williams, Neighbors and Jackson (2003).

8 These examples are based on in-depth interviews with African-American residents of Nashville, TN. See Gideon's Army (2016). Similar examples and findings are reported elsewhere, see for example, Bell, Hopson, Craig and Robinson (2014). 


\subsection{Harm to others in society}

Individuals who are not in the targeted racial minority group might also be harmed. They might simply dislike the fact that fellow citizens are being targeted - either for altruistic reasons ${ }^{9}$ or due to an overarching preference for fairness. ${ }^{10}$ Regardless of the underlying motivation, some individuals might be willing to pay more to live in a society that does not target certain racial minorities.

\subsection{Police and criminal justice system costs}

To the extent that a police encounter is racially motivated and not objectively based on sound policing techniques, ${ }^{11}$ the time spent by police officers could have been spent more productively on other public safety activities. In addition, if such an encounter escalates beyond the initial police contact and involves other aspects of the criminal justice or legal system (e.g., unwarranted arrests), additional costs might accrue.

In addition, to the extent members of the racially targeted minority lose trust in the police there might be serious consequences for law enforcement and hence society more generally. For example, members of a racial or ethnic minority who do not trust the police might be less willing to report a crime or otherwise cooperate with a police investigation. Their reluctance might lead to reduced arrest and/or conviction rates and potentially to increases in subsequent crime.

\section{Estimating the social harm from a racially targeted police encounter}

As noted above, this paper largely considers the question of estimating the cost of a racially targeted police encounter for purposes of social benefit-cost analysis. As such, the appropriate conceptual model for estimating social harm would be an $\boldsymbol{e x}$ ante analysis - what should society pay to reduce the incidence of future

9 See Bergstrom (2006) for a discussion of how altruism should be valued in the context of benefit-cost analysis. For evidence that individuals are willing to pay to improve the quality of life of others, see Viscusi, Magat and Forrest (1988).

10 For evidence that individuals value and are willing to pay for fairness, see for example, Kahneman, Knetsch and Thaler (1986).

11 See Section IV.B. for a discussion of how one might define racially motivated police encounters relative to purely utilitarian or random/race-neutral motivations. 
racially targeted police encounters. An alternative model could be used for compensation purposes - what should society pay ex post to victims of a racially targeted police encounter. However, as stated at the outset, this paper focuses on benefitcost analysis, not victim compensation. Generally, for a harmful activity, the ex post (willingness-to-accept) compensation amount will be higher than the ex ante (willingness-to-pay) value. ${ }^{12}$ While this paper attempts to identify ex ante costs, in some cases, it is difficult to estimate ex ante costs and a hybrid approach might be used.

There are two conceptual approaches one could use to estimate the harm from a racially targeted police encounter - a "bottom up" approach and a "top down" approach. ${ }^{13}$ The bottom up approach would attempt to identify and monetize each of the component harms. An alternative "top down" approach would attempt to incorporate all such costs using a single estimation methodology such as estimating society's willingness-to-pay to avoid a racially targeted police encounter. There are various survey methods designed to estimate willingness-to-pay including contingent valuation surveys and discrete choice experiments. These methods have been used extensively to value environmental amenities, food, safety and health risks, as well as other nontraded goods and services, ${ }^{14}$ and more recently adapted to criminal victimization. ${ }^{15}$ Such a survey would include a random sample of the entire population, but might also need to be certain that the targeted minority group is adequately represented in the sample (or oversampled if necessary). In theory, using this methodology would fully capture society's willingness-to-pay to reduce unwarranted police encounters. However, like any estimation methodology, there are considerable controversies and methodological complexities to designing such a survey that would need to be considered. ${ }^{16}$

12 There are various reasons why this might be true. For example, willingness-to-pay estimates might be constrained by ability-to-pay. However, they will also differ based on available substitutes (see Hanemann, 1991). Cohen (2005) discussed the difference between these two approaches in the context of crime costs.

13 See Cohen (2010) for comparison of the "bottom up" versus "top down" approaches to estimating the cost of crime. The approach taken here is very similar and largely based on my previous work on estimating the cost of crime.

14 See e.g., Mitchell and Carson (1989) and Carson (2012).

15 See e.g., Ludwig and Cook (2001), Cohen, Rust, Steen and Tidd (2004), Cohen (2015) and Picasso and Cohen (2017).

16 See Cohen (2010) for a review of the methodology applying contingent valuation to crime valuation, and Carson and Louviere (2017, this issue) for a discussion of how the discrete choice experiment method can be applied to crime control programs such as community policing. For a contrarian view arguing that contingent valuation is a hopeless exercise, see Hausman (2012). The main (well-known) concerns with survey design include hypothetical bias, the difference between WTP and WTA, and the embedding effect. 
An alternative approach to these "stated-preference" methodologies to estimating willingness-to-pay would be to rely upon actual market data ("revealed preference"), using data on housing price differentials, for example. Although economists generally prefer revealed preference approaches, there are numerous practical problems with utilizing such studies in the context of unwarranted police searches. For example, many of these encounters are likely to take place outside the individual's neighborhood - leaving housing price studies of limited value. Nevertheless, further studies might be warranted - even if to provide a lower-bound estimate of costs. For example, one might consider examining the change in housing and/or rental prices, or measuring averting behavior such as changed commuting patterns following an incident of unwarranted police violence in a local neighborhood. ${ }^{17}$ Similar studies have been used to estimate the value of avoiding a sex offender (Linden \& Rockoff, 2008).

Table 1 identifies the individual cost components and estimation methods to monetize the harm from a racially targeted police encounter, and follows the categories and discussion in Section 2 above. Due to the difficulty of estimating some ex ante costs, methods for identifying ex post costs are also included. For the targeted individual whose police encounter escalates into unlawful physical harm, it should be possible to estimate any medical costs, lost wages, and then value the pain, suffering and lost quality of life associated with those injuries (or death). There is a large literature and various methodologies for estimating these losses - applied to victims of accidents and crime victims (see e.g., Miller, 1993; Cohen, Miller \& Rossman, 1993; Miller, Cohen \& Wiersema, 1996). However, these estimates are ex post. For an ex ante analysis, one could potentially conduct a willingness-to-pay, stated-preference study to estimate the targeted population's value of reducing this risk.

Next, however, for all targeted individuals regardless of whether they suffer physical harm, there is the potential for significant harm due to fear. Once again, an ex ante willingness-to-pay study might be an approach to estimate this cost. Presumably, the willingness-to-pay to avoid an unwarranted police encounter would capture both the expectation of physical harm as well as fear. Thus, one study would incorporate both cost components. In theory, an ex post analysis might first estimate the objective risk of physical harm from unwarranted police encounters and then apply that probability to the actual average physical harm to those who are physically harmed. An additional risk premium might be added to this harm

17 These studies are likely to be difficult to implement due to endogeneity of the measures of interest. For example, unwarranted police encounters are also likely to occur in neighborhoods with higher crime rates. However, in theory, a difference-in-difference study might be implemented comparing neighborhoods where such encounters occur to those in which they do not. 
Table 1 Component costs of targeted police encounters.

\begin{tabular}{|c|c|c|}
\hline Harm Category & Details on Harm & Notes on Estimation \\
\hline \multicolumn{3}{|l|}{ Targeted Individual } \\
\hline $\begin{array}{l}\text { Physical harm (or } \\
\text { death) }\end{array}$ & $\begin{array}{l}\text { Medical costs, lost wages, pain } \\
\& \text { suffering, lost quality of life }\end{array}$ & $\begin{array}{l}\text { Ex ante: willingness-to-pay. Ex } \\
\text { post: dollar losses plus estimate of } \\
\text { nonpecuniary losses. }\end{array}$ \\
\hline Fear of harm & $\begin{array}{l}\text { Perceived risk of physical } \\
\text { harm while undergoing } \\
\text { unwarranted encounter }\end{array}$ & $\begin{array}{l}\text { Ex ante: willingness-to-pay. Ex } \\
\text { post: objective risk of physical } \\
\text { harm (above), increased by risk } \\
\text { premium. }\end{array}$ \\
\hline $\begin{array}{l}\text { Opportunity cost of } \\
\text { time }\end{array}$ & $\begin{array}{l}\text { Average time spent by } \\
\text { individual dealing with police } \\
\text { encounter and collateral } \\
\text { consequences }\end{array}$ & $\begin{array}{l}\text { Ex ante: could be incorporated into } \\
\text { willingness-to-pay study. Ex post: } \\
\text { valued by wage rate or other } \\
\text { economic measures of opportunity } \\
\text { costs }\end{array}$ \\
\hline Humiliation cost & $\begin{array}{l}\text { Psychic costs associated with } \\
\text { having been targeted beyond } \\
\text { risk or actual injury. }\end{array}$ & $\begin{array}{l}\text { Ex ante: could be incorporated into } \\
\text { willingness-to-pay study. Ex post: } \\
\text { difficult to "ask" targeted } \\
\text { individuals to place dollar value on } \\
\text { their ex post humiliation costs. } \\
\text { However, in theory this is possible. }\end{array}$ \\
\hline \multicolumn{3}{|l|}{$\begin{array}{l}\text { Members of Racial } \\
\text { Minority }\end{array}$} \\
\hline $\begin{array}{l}\text { Fear of unwarranted } \\
\text { encounter }\end{array}$ & $\begin{array}{l}\text { Perceived risk of an } \\
\text { unwarranted encounter }\end{array}$ & $\begin{array}{l}\text { Ex ante: incorporated in study } \\
\text { above. Ex post: costs identified } \\
\text { above, multiplied by probability } \\
\text { and risk premium. }\end{array}$ \\
\hline Humiliation costs & $\begin{array}{l}\text { Perceived humiliation from } \\
\text { being member of targeted } \\
\text { minority group. }\end{array}$ & $\begin{array}{l}\text { Ex ante: incorporated in study } \\
\text { above. Ex post: costs identified } \\
\text { above, multiplied by probability } \\
\text { and risk premium. }\end{array}$ \\
\hline Avoidance behaviors & $\begin{array}{l}\text { Actions taken to reduce risk of } \\
\text { unwarranted police encounter. }\end{array}$ & $\begin{array}{l}\text { Ex ante: in theory, this would be } \\
\text { included in a willingness-to-pay } \\
\text { survey if properly designed. } \\
\text { Alternative approach would be to } \\
\text { survey public to determine } \\
\text { behaviors and opportunity costs. } \\
\text { Ex post: not applicable. }\end{array}$ \\
\hline
\end{tabular}

Continued on next page.

to account for risk aversion. However, if the purpose of the harm estimate is to generate aggregate costs, care must be taken not to double count losses.

Next, we might estimate the average opportunity cost of time for an individual who is racially targeted in a police encounter. Once again, an appropriately designed ex ante willingness-to-pay study might estimate this cost. An ex post analysis would 
Table 1 (Continued).

\section{Other Members of}

\section{Society}

Value of living in

nondiscriminatory

society

Police and Criminal Justice System Costs

Resources wasted on socially unproductive activities
Opportunity cost of time spent by police and other criminal justice agencies.
Willingness-to-pay contingent valuation or discrete choice survey.
Lack of trust leading to reduced clearance or conviction rates
Higher crime rates and/or lack of criminal convictions
At a minimum, assume equal to hourly cost of each personnel employed (including overhead rate). This ignores any additional social benefit from time spent on alternative activities.

Crimes can be valued using existing techniques. However, studies would need to estimate increased crime rate due to lack of trust.

value this time directly based on a survey of the average time spent on a police encounter and the opportunity cost of time. ${ }^{18}$ Finally, the targeted minority member might suffer psychic costs associated with the humiliation of being targeted. Once again, an appropriately designed ex ante willingness-to-pay study might incorporate this cost. Developing an ex post estimate of humiliation costs might be particularly difficult as one cannot simply ask the individual for a dollar value of this cost there is no incentive to provide accurate information (and they might not even be able to provide a dollar number if asked). In theory, however, it might be possible to design a survey that elicits truthful values. An alternative approach might be to rely upon informed third parties such as juries (see e.g., Cohen, 1988; Aiken \& Zamula, 2009; Miller, Cohen \& Hendrie, 2017) ${ }^{19}$ or to combine QALY measures from a panel of medical professionals with externally derived estimates of the statistical value of life (see e.g., Miller, 2000).

Similar estimation approaches might be used to monetize the harm to members of the racial minority who are not necessarily targeted themselves with an unwarranted police encounter. If an ex ante willingness-to-pay approach is used to estimate harm, by definition, all members of the racial minority are at risk of

18 See e.g., Haveman and Weimer (2015) on estimating the opportunity cost of time.

19 The use of jury awards have been justified partly based on the fact that society has deemed their use to be appropriate in valuing tort claims. While jury awards have been used to value crime, juries are making judgments without being subject to their own budget constraints and are instead providing ex post compensation with others' money; this is not the preferred measure for ex ante policy evaluations. 
unwarranted targeting; hence a survey would cover both those who are ultimately targeted and those who are not. In the case of ex post estimates, in theory, one could estimate the probability to each member of that minority group, multiplied by the harm if they are subject to an unwarranted police encounter, and then apply a risk premium to value. In addition, however, an additional component of "avoidance behavior" would likely require a random survey of members of the minority group to identify and quantify these avoidance behaviors.

Although in theory there might be some innovative approaches to uncover revealed preference estimates of the value of living in a racially nondiscriminatory society, I am unaware of any such studies or approaches. Instead, since this is largely a nontraded (nonmarket) good, it would appear that the most appropriate methodology to estimate harm to the public at large from living in a society that engages in racially targeted policing is to conduct a willingness-to-pay survey. Presumably, such a study might be conducted along with one that targets members of the racial minority and use similar descriptive information and questions.

Finally, the most straightforward way to estimate the cost of police and criminal justice resources, would be to utilize police and criminal justice expenditure data and combine the "per hour" cost with an estimate of the time spent by each component organization. Data on the average cost of police, courts, etc., are generally available through surveys and special studies, although per unit costs are not straightforward to estimate. ${ }^{20}$ This approach might also be appropriate for estimating the opportunity cost of time spent by police or law enforcement when they otherwise would not be engaged in a racially unwarranted encounter or in dealing with an increased crime rate brought about by lack of trust in police. However, one would still need to estimate the impact of a lack of trust on these outcomes.

\section{Complexities in defining and estimating harm from a racially targeted police encounter}

While this paper mostly focuses on estimating the cost of a racially targeted police encounter, it has largely ignored the question of how to define such an event in the first place. The definition of a racially targeted police encounter is not only subject

20 The Bureau of Justice Statistics publishes results of an annual survey of local law enforcement expenditures (Justice Expenditure and Employment Extracts, https://www.bjs.gov/index.cfm?ty=pbdet ail\&iid=5239); however, this does not have disaggregated costs. Several states have conducted detailed studies of the cost of individual police and criminal justice activities, including Washington State (Washington State Institute for Public Policy Studies, Benefit-Cost Analysis Technical Documentation, December 2016, http://www.wsipp.wa.gov/TechnicalDocumentation/WsippBenefitCostTechnicalDocu mentation.pdf) and Vermont (Criminal Justice Consensus Cost-Benefit Working Group Final Report, May 2014, http://www.leg.state.vt.us/reports/2014ExternalReports/301407.pdf). 
to alternative interpretations, but members of the targeted racial minority might be misinformed about their risk of an unwarranted encounter. This section considers some of the important implications of these complexities.

\subsection{Cost of "reducing" racially targeted police encounters}

Depending upon the goal and budget of police agencies, it is possible that reducing police targeting of racial minorities will result in an increase in encounters with members of the majority of the population. This might inadvertently increase the direct cost of police encounters with "innocent" members of the majority - which clearly also has a cost in terms of hassle, time, and potentially the risk of a harmful (unwarranted) encounter. Thus, to some extent, society might be decreasing some of the costs imposed on a racial minority at the expense of the majority. One might argue that this is appropriate on fairness grounds, but it would be hard to argue solely on economic efficiency. ${ }^{21}$ Both of these individuals were "innocent" and if one is stopped by the police instead of the other, the net effect appears to be zero. On the other hand, it is likely that the costs imposed on the typical innocent minority who is targeted are higher than the costs imposed on the typical innocent member of the majority. ${ }^{22}$ In particular, the risk and/or fear of harm and the humiliation costs are likely to be much higher for the minority individual due to the concern of racial bias itself.

\subsection{Definition of a racially targeted police encounter}

Before monetizing the harm from a racially targeted police encounter, we must first define the term "racially targeted." If there is no "targeting" at all, police encounters would be entirely random. However, this is unlikely to be an efficient use of police resources, and instead police might appropriately "target" drivers of cars with expired license plates, for example, or individuals who meet a detailed description of a robbery suspect that occurred nearby. On the other hand, few would argue that it is appropriate, for example, to stop and frisk all African-American males nearby the scene of a robbery when the only description of the offender is that he was African-American. With these examples in mind, suppose as a hypothetical

21 See Viscusi and Zeckhauser (2003), for an example of the trade-off of civil liberties versus efficiency in the case of targeting certain minorities in an attempt to reduce terrorism.

22 Regardless of the ultimate social welfare impact, this example highlights the importance of analyzing the distributional impact of policy alternatives when conducting a benefit-cost analysis. 
that African-Americans represent $10 \%$ of a community but they represent $20 \%$ of offenders. Would we consider a 20\% African-American encounter rate (twice their representation in the population but equal to their offending rate) to be racial targeting? From a purely utilitarian and legal perspective, this might be considered appropriate "targeting." However, for the larger percentage of African-Americans who are stopped and are innocent, they might have different views altogether. ${ }^{23}$ Indeed, they might perceive that they have been targeted because of their race. This example highlights the difficulty of even defining racial targeting - targeted individuals might feel the harm even if objective police behavior suggests otherwise. This leads to an even more complex but related issue, considered next.

\subsection{Innocent "targeted" individual: perception versus objective bias}

Finally, it is possible that members of a minority group who encounter a police officer are misinformed about whether or not there is targeted policing and whether in fact members of the minority group have police encounters at a rate greater than their population or their group's rate of offending. These misperceptions are likely to affect both stated preferences on willingness-to-pay surveys as well as behaviors. For example, suppose members of the minority community overestimate the likelihood of targeted police encounters. In that case, in a contingent valuation survey, respondents might overstate their valuation of targeted police encounters. Similarly, members of the minority community might engage in more precautionary behaviors than would be in their own interest if they were appropriately informed. The question from a public policy (and benefit-cost) perspective is whether public decisions should be based on objective or perceived risks.

This issue has been previously discussed in the context of environmental policies. ${ }^{24}$ Portney (1992) examines a similar question in the context of the hypothetical town of Happyville, where residents are each willing to pay for a water purification system to reduce their fear of carcinogens in the water supply despite overwhelming scientific consensus that there are no carcinogens in the water. A common response to this hypothetical is to provide residents with objective risk information, and if all else fails, to base any benefit-cost analysis on objective risks (see e.g., Viscusi \& Gayer, 2016: 81). However, this might not be appropriate in some cases. For example, to the extent residents take costly precautionary behaviors in response

23 This hypothetical ignores the difficulty in defining and measuring an appropriate rate of targeting. See, for example, Ridgeway and MacDonald (2010).

24 See Cohen $(2010,104-6)$ for a more detailed discussion of this issue. 
to their misperceptions, real social costs might be incurred. Moreover, although outside researchers might view citizens as being irrational or having lack of information; these researchers might not be accurately observing citizen's risk aversion, time preferences, expectations of future political scenarios, and so forth, and thus they might be misjudging rationality and/or full information. In addition, even if citizens misjudge absolute risk levels, they might be able to value a change in risk levels - which is the way most contingent valuation studies are constructed. Johansson-Stenman (2008) explicitly models misperception and shows that in some cases a second-best solution might call for more protection than "objective" risks might suggest in order to enhance welfare through reduction in anxiety and avoidance behaviors. Thus, the solution is likely to be more complicated than solely basing benefit-cost analysis on objective risks. At the very least, attempts should be made to understand the differences between willingness-to-pay using objective versus perceived risks and conduct sensitivity analysis, examine alternative secondbest solutions, and so forth. ${ }^{25}$

The comparison to unwarranted police encounters appears to be straightforward, since the risk of such an encounter not only induces fear but it also causes members of the minority group to take costly avoidance behaviors as described above. Thus, if there are widespread misperceptions that cannot easily be changed, according to the Johansson-Stenman model, it might be welfare enhancing to reduce targeted policing further than one might objectively wish to do - so that members of the minority group reduce their mental anguish and avoidance behaviors.

Thus, one of the key issues that must be resolved in determining the appropriate methodology for estimating the cost of unwarranted police encounters is whether to base valuation on the public's perception of value or some other measure deemed to be more objective by the researcher. While this issue has not been fully resolved and differences of opinion are likely to persist, future research could (and should) explore this issue explicitly. For example, one approach might be to explicitly design a survey that asks half of the sample to respond without providing any information and the other half to respond only after receiving objective data. This would allow researchers to determine both the perceived value of reducing unwarranted police encounters and the value of "better information."

25 Blomquist (2004) reviews the literature on valuing risk reductions in the context of environmental and safety risks including how adjustments might be made to account for risk misperceptions. 


\section{Concluding remarks}

This paper has attempted to provide a taxonomy of the social costs associated with an unwarranted/racially targeted police encounter. Regardless of the extent to which racially targeted police encounters occur, their impact is real. Members of the racial group who perceive they are being targeted oftentimes suffer from fear and/or engage in costly behavioral changes to avoid being targeted. Those who believe they have been targeted might suffer additional humiliation costs in addition to any direct harm. In addition, members of the public at large also suffer to the extent they believe and dislike being members of an unfair society.

The fact that it is difficult to quantify and monetize the harm associated with a racially targeted police encounter does not mean the exercise is futile. Indeed, the problem is no less challenging than valuing the spotted owl, the social cost of carbon, or the reduction in fear due to airport security controls designed to reduce terrorism. Economists routinely monetize these as well as many other nontraded goods for use in public policy settings. Of course, any estimates will be subject to considerable uncertainty and best practice suggests the need for a transparent approach using state-of-the-art methodologies (including providing sensitivity analysis and confidence intervals when possible). The alternative - claiming that these social costs are too difficult to monetize - does not obviate the need for making difficult policy choices. Even if not monetized, once a policy decision has been made, there will be an "implicit" price placed on unwarranted police encounters.

\section{References}

Aiken, Deborah Vaughn \& Zamula, William W. (2009). Valuation of Quality of Life Losses Associated with Nonfatal Injury: Insights from Jury Verdict Data. Review of Law and Economics, 5(1), 293-310.

Bell, Gina Castle, Hopson, Mark C., Craig, Richard \& Robinson, Nicholas W. (2014). Exploring Black and White Accounts of 21st-Century Racial Profiling: Riding and Driving While Black. Qualitative Research Reports in Communication, 15(1), 33-42.

Bergstrom, Theodore C. (2006). Benefit-Cost in a Benevolent Society. The American Economic Review, 96, 339-351.

Blomquist, Glenn C. (2004). Self-Protection and Averting Behavior, Values of Statistical Lives, and Benefit Cost Analysis of Environmental Policy. Review of Economics of the Household, 2, 89-110.

Carson, Richard T. (2012). Contingent Valuation: A Practical Alternative When Prices Aren't Available. Journal of Economic Perspectives, 26, 27-42.

Carson, Richard T. \& Louviere, Jordan (2017). Estimation of Broad-Scale Tradeoffs in Community Police Policies. Journal of Benefit Cost Analysis, 8(3), 385-398. 
Cohen, Mark A. (2015). Willingness to Pay to Reduce White Collar and Corporate Crime. Journal of Benefit-Cost Analysis, 6(2), 305-324.

Cohen, Mark A. (2010). Valuing Crime Control Benefits Using Stated Preference Approaches. In John K. Roman, Terence Dunworth \& Kevin Marsh (Eds.), Cost-Benefit Analysis and Crime Control (Chapter 4, pp. 73-118). Washington, DC: Urban Institute Press.

Cohen, Mark A. (2005). The Costs of Crime and Justice. New York, NY: Routledge.

Cohen, Mark A., Rust, Roland, Steen, Sara \& Tidd, Simon (2004). Willingness-to-Pay for Crime Control Programs. Criminology, 42(1), 86-106.

Cohen, Mark A., Miller, Ted R. \& Rossman, Shelli B. (1993). Victim Costs of Violent Crime and Resulting Injuries. Health Affairs, 12(4), 186-197.

Cohen, Mark A. (1988). Pain, Suffering, and Jury Awards: A study of the Cost of Crime to Victims. Law and Society Review, 22(3), 537-555.

Gideon's Army. 2016. Driving While Black: A Report on Racial Profiling in Metro Nashville Police Department Traffic Stops. Available at: https://drivingwhileblacknashville.word press.com/the-report-6/.

Hanemann, W. Michael (1991). Willingness to Pay and Willingness to Accept: How Much Can They Differ? The American Economic Review, 81(3), 635-647.

Hausman, Jerry (2012). Contingent Valuation: From Dubious to Hopeless. Journal of Economic Perspectives, 26(4), 43-56.

Haveman, Robert H. \& Weimer, David L. (2015). Public Policy Induced Changes in Employment: Valuation Issues for Benefit-Cost Analysis. Journal of Benefit-Cost Analysis, 6, $112-153$.

Havrilesky, Thomas (1993). The Misapplication of the Hedonic Damages Concept to Wrongful Death and Personal Injury Litigation. Journal of Forensic Economics, 6(2), 93-98.

Hickman, Matthew J. (2006). Citizen Complaints about Police Use of Force. Washington, DC: U.S. Department of Justice, Office of Justice Programs, Bureau of Justice Statistics; NCJ 210296 (June).

Johansson-Stenman, Olof (2008). Mad Cows, Terrorism and Junk Food: Should Public Policy Reflect Subjective or Objective Risks? Journal of Health Economics, 27(2), 234-248.

Kahneman, Daniel, Knetsch, Kack T. \& Thaler, Richard H. (1986). Fairness and the Assumptions of Economics. The Journal of Business, 59(4), S285-S300.

Linden, Leigh \& Rockoff, Jonah E. (2008). Estimates of the Impact of Crime Risk on Property Values from Megan's Laws. The American Economic Review, 98(3), 1103-1127.

Ludwig, Jens \& Cook, Philip J. (2001). The Benefits of Reducing Gun Violence: Evidence from Contingent-Valuation Survey Data. The Journal of Risk and Uncertainty, 22(3), 207-226.

Miller, Ted R., Cohen, Mark A. \& Hendrie, Delia (2017). Noneconomic Damages Due To Physical and Sexual Assault: Estimates from Civil Jury Awards. Forensic Science and Criminology, 2(1), 1-10.

Miller, Ted R., Cohen, Mark A. \& Wiersema, Brian 1996. Victim Costs and Consequences: A New Look. National Institute of Justice Research Report, NCJ-155282.

Miller, Ted R. (2000). Valuing Nonfatal Quality of Life Losses with Quality-Adjusted Life Years: The Health Economist's Meow. Journal of Forensic Economics, 13(2), 145-167.

Miller, Ted R. (1993). Costs and Functional Consequences of US Roadway Crashes. Accident Analysis \& Prevention, 25(5), 593-607.

Mitchell, Robert Cameron \& Carson, Richard T (1989). Using Surveys to Value Public Goods: The Contingent Valuation Method. Washington: Resources for the Future. 
Picasso, Emilio \& Cohen, Mark A. 2017. Valuing the public's demand for crime prevention programs: a discrete choice experiment. Working Paper, available at http://ssrn.com/ab stract $=3015649$.

Portney, Paul R. (1992). Trouble in Happyville. Journal of Policy Analysis and Management, $11,131-132$.

Ridgeway, Greg \& MacDonald, John (2010). Methods for Assessing Racially Biased Policing. In Stephen K. Rice \& Michael D. White (Eds.), Race, Ethnicity, and Policing: New and Essential Readings (Chapter 7, pp. 180-204). New York: NYU Press.

Torres, Walter J. \& Bergner., Raymond M. (2010). Humiliation: Its Nature and Consequences. Journal of the American Academy of Psychiatry and the Law, 38(2), 195-204.

Viscusi, W. Kip (2000). Misuses and Proper Uses of Hedonic Values of Life in Legal Contexts. Journal of Forensic Economics, 13(2), 111-125.

Viscusi, W. Kip \& Gayer, Ted (2016). Rational Benefit Assessment for an Irrational World: Toward a Behavioral Transfer Test. Journal of Benefit Cost Analysis, 7(1), 69-91.

Viscusi, W. Kip, Magat, Wesley A. \& Forrest, Anne (1988). Altruism and Private Valuation of Risk Reduction. Journal of Policy Analysis and Management, 7(2), 227-245.

Viscusi, W. Kip \& Zeckhauser, Richard J. (2003). Sacrificing Civil Liberties to Reduce Terrorism Risks. Journal of Risk and Uncertainty, 26, 99-120.

Williams, David R., Neighbors, Harold W. \& Jackson, James S. (2003). Racial/Ethnic Discrimination and Health: Findings from Community Studies. American Journal of Public Health, 93(2), 200-208. 